\title{
Pengembangan Bahan Ajar Nahwu Berbasis Kontrastif Untuk Mengatasi Interferensi Bahasa Indonesia Terhadap Bahasa Arab
}

\author{
Afif Kholisun Nashoih \\ Universitas KH. A. Wahab Hasbullah(UNWAHA)Jombang \\ afif.nashoih90@gmail.com \\ M. Faridl Darmawan \\ Universitas KH. A. Wahab Hasbullah (UNWAHA) Jombang \\ faridldarmawan@unwaha.ac.id
}

\begin{abstract}
This research is motivated by the many contents of the elements of Indonesian interference in Insha 'students of the Arabic Language Education University of KH. A. Wahab Hasbullah. The interference is caused by the lack of students' understanding of syntax rules. Therefore, the purpose of this research is to develop Arabic syntax teaching materials as a solution to overcome Indonesian interference with Arabic. The method used in this research is $R \& D$ by adopting the ADDIE development model (analysis, design, develop, implementation, evaluation). This research produces Arabic syntactic teaching material which is presented through a comparison between the rules of Arabic and Indonesian, and contains material that emphasizes the aspect of function, which includes the material formation of sentences as well as variations and complement. After going through the validation stage with a very valid qualification of $89.1 \%$, the results of the data analysis state that the developed teaching material is able to improve the learning outcomes of students in the course of nahwu (Arabic syntax) which certainly goes hand in hand with increasing their understanding. This increase has a significant effect as a solution to minimize the level of interference. This is proven through further analysis by comparing the results of the pretest which reached an average of $57.26 \%$ and the posttest which reached an average of $79.03 \%$ so that it can be interpreted that grammatical errors due to interference factors can be overcome.
\end{abstract}

Keywords: Arabic syntax, contrastive, interference 


\begin{abstract}
Abstrak
Penelitian ini dilatarbelakangi oleh banyaknya muatan unsur-unsur interferensi bahasa Indonesia dalam insya' para mahasiswa Pendidikan Bahasa Arab Universitas KH. A. Wahab Hasbullah. Adanya interferensi tersebut disebabkan minimnya tingkat pemahaman para mahasiswa terhadap kaidah sintaksis. Oleh karena itu, dilakukannya penelitian ini bertujuan untuk mengembangkan bahan ajar nahwu sebagai solusi untuk mengatasi interferensi bahasa Indonesia terhadap bahasa Arab. Metode yang digunakan dalam penelitian ini adalah R\&D dengan mengadopsi model pengembangan ADDIE (analisys, design, develop, implementation, evaluation). Penelitian ini menghasilkan bahan ajar nahwu yang disajikan melalui perbandingan antara kaidah bahasa Arab dan bahasa Indonesia, dan berisi materi-materi yang menekankan aspek fungsi, yaitu meliputi materi pembentukan kalimat serta variasi dan pelengkapnya. Setelah melalui tahap validasi dengan kualifikasi sangat valid sebesar $89,1 \%$, hasil analisis data menyatakan bahwa bahan ajar yang dikembangkan mampu meningkatkan hasil belajar para mahasiswa dalam matakuliah nahwu (sintaksis Arab) yang tentu berjalan beriringan dengan meningkatnya pemahaman mereka. Peningkatan tersebut memiliki pengaruh signifikan sebagai solusi meminimalkan tingkat interferensi. Hal ini dibuktikan melalui analisis lanjutan dengan membandingkan antarahasil pretes yang mencapai rata-rata $57,26 \%$ dan postes yang mencapai rata-rata 79,03\%sehingga dapat diartikan bahwa kesalahan-kesalahan gramatikalkarena faktor interferensi dapat teratasi.
\end{abstract}

Kata Kunci: Sintaksis bahasa Arab, kontrastif, interferensi

\title{
Pendahuluan
}

Mempelajari bahasa kedua memang bukan perkara mudah. Selain harus bisa memahami simbol-simbol kebahasaan, pembelajar juga harus bisa menggunakannya dalam berkomunikasi. Selain itu juga harus memahami kaidah bahasa sebagai modal utama untuk berbahasa secara baik dan benar. Kaidah kebahasaan ini menjadi jembatan bagi pembelajar untuk bisa menguasainya. Buah dari ketidakpahaman kaidah ini akan menimbulkan banyak permasalahan, di antaranya adalah terjadinya kesalahan-kesalahan berbahasa.

Sebagian besar ilmuan menganggap bahwa kesalahan-kesalahan dalam menggunakan bahasa kedua atau asing disebabkan adanya pengaruh yang kuat 
oleh bahasa pertama atau bahasa Ibu. ${ }^{1}$ Dengan kata lain, penuturan bahasa kedua mengalami anomali serta pencemaran akibat masuknya unsur-unsur bahasa Ibu. Dalam khazanah linguistik, fenomena ini disebut dengan interferensi.

Interferensi adalah sebuah fenomena penggunaan bahasa yang diresapi bahasa lain. ${ }^{2}$ Gejala munculnya interferensi acapkali terjadi pada masyarakat mulitilingual, atau masyarakat yang mampu menguasai dua bahasa atau lebih, termasuk para pembelajar bahasa asing. al-Khuli mengungkapkan bahwa interferensi sebuah bahasa dalam bahasa lain hanya akan terjadi jika seseorang menguasai dua bahasa saat memproduksi salah satu dari keduanya dalam ta'bir kalamiy (tutur kata) atau ta'bir kitabiy (tulisan). ${ }^{3}$

Bagi orang Indonesia yang mempelajari bahasa Arab, fenomena interferensimenjadi salah satu kendala yang sulit diatasi. Hal ini dikarenakan kuatnya dominasi bahasa Ibu, baik bahasaIndonesia ataupun bahasa daerah yang berjalan beriringan dengan lemahnya pemahaman gramatikal serta tradisi berbahasa Arab yang benar. Oleh sebab itu, merebaknya pengaruh bahasa Indonesia terhadap bahasa Arab menjadikan penuturan bahasa Arab terdengar tidak elok, aneh, dan tidak lazim. Seolah penggunaan bahasa Arab terasa Indonesia, karena hanya pemindahan bahasa tanpa mengindahkan aspek gramatikal.

Tingkat pemahaman Nahwu menjadi salah satu faktor utama terjadinya interferensi. Hal ini dibuktikan dari penelitian yang dilakukan sebelumnya, bahwa terdapat 8 aspek yang menjadi titik pusat terjadinya kesalahan berbahasa Arab yang diakibatkan oleh interferensi, yaitu aspek kala, persesuaian, tarkib idhafah, tarkib na'tiy, kalimat pasif, penanda jumlah, verba yang terikat dengan preposisi, serta aspek penggunaan kata "kana" dan "lianna" sebagai terjemah dari kata "ada" dan "karena" tanpa adanya kepatuhan terhadap kaidah. ${ }^{4}$ Maka dari itudiperlukan adanya penekanan pembelajaran nahwu, khususnya aspek-aspek yang seringkali menjadi pemicu terjadinya interferensi.

Dalam khazanah linguistik Arab, pengertian nahwu tidak monolitik, artinya bahwa banyak sekali redaksi berbeda dalam mendefinisikan nahwu. Hanya saja dalam terminologi yang paling masyhur disebutkan bahwa nahwu

${ }^{1}$ Faisal Mubarak Seff dan Muhammad Mukhtar, "Al-Muhadatsah al-Yaumiyyah Wa Tadakhkhul Lughah al-Umm Fiha," Prosiding Pertemuan Ilmiah Internasional Bahasa Arab XI, 13 Juli 2018, 1057.

${ }^{2}$ Abdul Chaer dan Leoni Agustina, Sosiolinguistik: Perkenalan Awal (Jakarta: Rineka Cipta, 2010), 160-61.

${ }^{3}$ Muhammad Ali Al-Khuli, “Ta'tsiru al-Tadakhkhul al-Lughawiy fiy Ta'allumi alLughah al-Tsaniyah wa Ta'limuha," Majallah Jami'ab Malik Saud 1, no. 2 (1989): 111.

${ }^{4}$ Afif Kholisun Nashoih, "Pola Interferensi Sintaksis Bahasa Indonesia Dalam Bahasa Arab Pada Insya' Mahasiswa Pendidikan Bahasa Arab," Prosiding Konfererensi Nasional Babasa Arab 5, no. 5 (2019): 660 . 
adalah ilmu yang mengkaji perubahan akhir tiap kata dalam kalimat disebabkan adanya amil yang mendahuluinya. Perubahan akhir kata dalam nahwu merupakan penentu jabatan tiap kata dalam sebuah kalimat. Meski hanya berkutat pada akhir kata, namun berperan besar dalam menjaga lafad dari kesalahan berbahasa. Tidak berlebihan jika dikatakan bahwa nahwu merupakan ruh bahasa Arab,dan senantiasa menjadi prioritas utama dalam belajar bahasa Arab. Sehingga kekurangan dalam memahami nahwuakan berbuah ketidaksempurnaan dalam mempelajari bahasa Arab. Meski demikian, urgensinya untuk dipelajari berbanding terbalik dengan sulitnya ilmu tersebut untuk dipahami.

Munculnya anggapan bahwa nahwu itu kompleks, rumit, dan susah dipahami bisa jadi disebabkan faktor internal dan eksternal. Dalam faktor internal, beberapa linguis berpendapat bahwa nahwu dibangun atas dasar logika dan hal yang bersifat filosofis, sehingga bobot filosifisnya lebih berat dibandingkan tujuan nahwu sebagai jembatan yang dapat mempermudah belajar bahasa Arab. ${ }^{5}$ Sedangkan dalam faktor eksternal, Wahab mengungkapkan bahwa secara praktis, nahwu susah dipahami karena dua hal, yaitu buku-buku atau bahan ajar yang tradisional, serta masih digunakannya metode pembelajaran klasik, sehingga pembelajaran nahwu terkesan kurang inovatif. ${ }^{6}$

Salah satu upaya untuk mengatasi problem kesulitan memahami sintaksis atau nahwu adalah digunakannya pendekatan kontrastif. Ia merupakan pisau analisa yang membandingkan sistem dua bahasa atau lebih. ${ }^{7}$ Hal yang sama dikemukaka oleh Thu'aimah dan al-Naqah yang dikutip oleh Raswan bahwa analisis kontrastif adalah studi komparasi terhadap dua bahasa atau lebih untuk menemukan persamaan dan perbedaan di antara dua bahasa tersebut. ${ }^{8}$ Pembandingan dua bahasa memberikan sumbangsih sebagai bahan masukan untuk pengajaran bahasa kedua, sehingga diharapkan bisa meminimalkan kesulitan belajar bahasa kedua (bahasa asing). ${ }^{9}$ Bahkan lahirnya analisis kontrastif disebabkan adanya tuntutan untuk mempermudah pemerolehan dan pembelajaran bahasa kedua atau bahasa Asing. ${ }^{10}$

${ }^{5}$ Afif Kholisun Nashoih, "Revolusi Ilmiah Thomas Kuhn dan Relevansinya Terhadap Pengembangan dan Pengembangan Ilmu Nahw," Jurnal Pusaka 6, no. 2 (27 Juni 2019): 15.

'Laode Abdul Wahab, "Pengembangan Bahan Ajar Qawaid Bahasa Arab Berbasis Mind Map untuk STAIN Kendari," Al-Izzah: Jurnal Hasil-Hasil Penelitian 9, no. 2 (1 November 2014): 68.

${ }^{7}$ Yayan Nurbayan, "Pengembangan Materi Ajar Balaghah Berbasis Pendekatan Kontrastif". Jurnal Bahasa Dan Seni," Babasa Dan Seni: Jurnal Bahasa, Sastra, Seni, Dan Pengajarannya 38, no. 1 (2010): 108.

${ }^{8}$ Raswan Raswan, “Tadris Al-Nahwi al-Tsani'Ala Asasi al-Taqabuliy,” Prosiding Pertemuan Ilmiah Internasional Bahasa Arab(13 Juli 2018): 1194.

${ }^{9}$ Tajudin Nur, "Analisis Kontrastif Dalam Studi Bahasa," Arabi: Joumal of Arabic Studies 1, no. 2 (31 Desember 2016): 67.

${ }^{10}$ Umi Hijriyah, Analisis Kontrastif Pembelajaran Bahasa Arab dan Babasa Indonesia (Lampung: Fakta Press, 2014), 8. 
Selama ini pemanfaatan hasil analisis kontrastif untuk tujuan pembelajaran terbilang minim. Sebagian besar penelitian analisis kontrastif hanya diarahkan untuk menemukan tipologi pengontrasan antara bahasa pertama dan kedua. Sejauh penelusuran yang dilakukan, hanya dua penelitian yang memanfaatkan analisis kontrastif untuk tujuan pembelajaran bahasa kedua, yaitu penelitian Yayan Nurbayan pada tahun 2010 tentang pengembangan materi ajar balaghah berbasis pendekatan kontrastif, dan penelitian yang dilakukan oleh Zagood tahun 2012 tentang pemanfaatan analisis kontrastif relative clauses dalam bahasa Arab dan Inggris sebagai bahan utama untuk mempermudah menerjemahkan dari bahasa Inggris ke dalam bahasa Arab. ${ }^{11}$ Kedua penelitian tersebut menunjukkan bahwa pendekatan kontrastif yang digunakan sebagai rujukan pedagogik memberikan efektifitas yang besar dalam pembelajaran bahasa kedua.

Berpijak pada hal-hal di atas, penelitian ini dilakukan bertujuan untuk mengembangkan bahan ajar nahwu untuk tingkat perguruan tinggi yang dikemas dengan menggunakan pendekatan kontrastif. Penelitian ini juga didasarkan atas hasil refleksi peneliti ketika mengajar di kelas. Banyaknya unsur-unsur interferensi bahasa Indonesia dalam tulisan berbahasa Arab para mahasiswa Pendidikan Bahasa Arab pada mata kuliah Maharah Kitabah menjadi kasus yang perlu mendapat perhatian lebih. Hal tersebut disebabkan oleh kurangnya tingkat pemahaman para mahasiswa dalam nahwu.

Pendekatan kontrastif sebagai landasan dalam penyusunan bahan ajar difungsikan untuk mengetahui persamaan dan perbandingan antara gramatikal Arab dan Indonesia. Sebagaimana dikemukakan oleh al-Khuli bahwa kajian kontrastif dapat menyingkap area-area kebahasaan yang terkena dominasi unsur interferensi. ${ }^{12}$ Oleh karenanya, bahan ajar ini akan memuat perbandingan nahwu bahasa Arab dan bahasa Indonesia, dengan harapan pembelajaran sintaksis menjadi lebih mudah, dan unsur interferensi bahasa Indonesia terhadap bahasa Arab dalam keterampilan menulis dapat diatasi.

Penelitian ini merupakan field research dengan menggunakan dua pendekatan sekaligus, yaitu kualitatif dan kuantitatif. Kualitatif digunakan untuk mendeskripsikan, menganalisis, dan menginterpretasikan data-data yang bukan berupa angka, yang diperoleh melalui studi pendahuluan serta observasi yang berkaitan dengan implementasi bahan ajar. Sedangkan pendekatan kuantitatif digunakan untuk memperoleh data berupa angka melalui uji kelayakan dan eksperimentasi bahan ajar. Adapun desain penelitian ini menggunakan model

\footnotetext{
${ }^{11}$ Mohammed Juma M Zagood, "A Contrastif Studi of Relativization in English and Arabic with Reference to Translation Pedagogy" (Duham University, 2012), I.

${ }^{12} \mathrm{Al}-\mathrm{Khuli}$, “Ta'tsiru al-Tadakhkhul al-Lughawiy fiy Ta'allumi al-Lughah al-Tsaniyah wa Ta’limuha," 117.
} 
pengembangan ADDIE yang terdiri dari 5 komponen, yaitu analysis, design, develop, implementation, dan evaluation. ${ }^{13}$

Instrumen yang digunakan untuk mengumpulkan data dalam penelitian ini adalah observasi, kuesioner, dan tes. Observasi digunakan untuk mengamati hal-hal yang berkaitan dengan pengembangan bahan ajar, sehingga sesuai dengan kebutuhan dan kondisi mahasiswa. Selain itu observasi juga dilakukan untuk mengamati secara intensif tentang uji coba produk saat proses pembelajaran. Kuesioner yang digunakan untuk mengetahui kelayakan produk, terdiri dari 2 jenis, yaitu kuesioner untuk ahli materi, dan kuesioner untuk mengetahui respon mahasiswa. Sedangkan tes digunakan untuk mengukur efektifitas penggunaan bahan ajar dalam meningkatkan pemahaman sintaksis, yang selanjutnya berkontribusi dalam mengatasi interferensi bahasa Indonesia terhadap bahasa Arab.

\section{Hasil dan Pembahasan}

\section{Realitas Lapangan}

Berdasarkan hasil studi pendahuluan, diperoleh informasi bahwa matakuliah nahwu yang ditempuh mahasiswa pendidikan bahasa Arab di Universitas KH. A. Wahab Hasbullah disajikan secara berjenjang, nahwu 1, 2, dan 3, serta ditempuh mahasiswa mulai semester 3 hingga semester 5 dengan bobot materi yang tentu saja berbeda. Pemerian matakuliah ini dimaksudkan sebagai salah satu pilar utama yang menopang keterampilan berbahasa, meliputi istima', kalam, qira'ah, dan kitabah.

Selama ini pembelajaran nahwu dilakukan secara konvensional, atau dengan kata lain proses pembelajarannya tidak jauh berbeda ketika para mahasiswa duduk di bangku sekolah, yaitu dengan cara penjelasan konsep beserta contoh-contohnya. Cara-cara tersebut dirasa tidak cukup efektif, karena tidak sedikit mahasiswa yang belum paham konsep nahwu, terlebih praktik. Di samping itu, sintaksis Arab atau nahwumemiliki materi yang memiliki batas liput sangat luas, ditambah istilah-istilah yang beragam dan juga asing di telinga sebagian mahasiswa. Sehingga tidak sedikit mahasiswa yang merasa kesulitan menerima materi ini.

Meski demikian, mereka sadar bahwa ruang lingkup sintaksis Arab hanya pada perubahan akhir kata dalam kalimat. Namun, ruang lingkup yang terbilang sempit itu melahirkan problem yang besar bagi mereka. Bahkan dalam ranah yang lebih besar, masalah ini berimbas pada semua matakuliah yang berkaitan erat dengan sintaksis, seperti empat matakuliah keterampilan bahasa, meliputi maharah istima', kalam, qiraah, dan kitabah. Atas dasar itu, diperlukan

${ }^{13}$ Sugiyono, Metode Penelitian Pendidikan: Pendekatan Kuantitatif, Kualitatif dan R\&D (Bandung: CV. Alfabeta, 2015), 200. 
penyederhanaan materi nahwu yang didasarkan aspek fungsional dan dibatasi pada kaidah-kaidah digunakan secara kominikatif sesuai kebutuhan mahasiswa.

\section{Pengembangan Bahan Ajar}

Berpijak dari analisis kebutuhan, bahan ajar yang dikembangkan tidak hanya memuat materi pada satu jenjang matakuliah nahwu saja, melainkan seluruh materi pokok dalam nahwu 1, 2, dan 3 yang kiranya dapat menopang keterampilan berbahasa Arab bagi mahasiswa, khususnya dalam menulis insya'. Oleh karena itu, bahan ajar ini terbilang cukup tebal dengan komposisi materi yang sifatnya fungsional, dan disajikan dengan menggunakan istilah-istilah nahwu yang dikontraskan dengan istilah dalam kacamata linguistik umum.

Bahan ajar yang dikembangkan ini mengedepankan aspek fungsi. Artinya bahwa muatan materi terbatas pada kaidah-kaidah kebahasaan yang dibutuhkan dalam berkomunikasi, baik lisan maupun tulisan. ${ }^{14}$ Oleh karena itu, bahan ajar ini tersusun atas 7 bagian besar, yaitu (1) selayang pandang lahirnya nahwu, (2) pintu masuk nahwu, (3) pembentukan kalimat, (4) pelengkap kalimat aspek genitif, (5) pelengkap kalimat aspek akusatif, (6) pelengkap berupa tawabi', (7) pelengkap kalimat berupa amil nawasikh.

Pada bagian pertama memuat informasi tentang sejarah lahirnya nahwu serta motivasi dan tujuan ilmu tersebut. Pengetahuan sejarah penting untuk diketahui para mahasiswa agar mereka paham bagaimana awal mula terbentuknya nahwu serta pola pemikiran para ahli nahwu yang terpecah-pecah sehingga berkembang aliran-aliran yang berbeda. Kemudian pada bagian kedua berisi tentang hal-hal mendasar dalam ilmu nahwu. Bagian ini terdiri dari dua bab yang menjadi dasar dalam sintaksis Arab, yaitu pembagian kata dalam bahasa Arab dan i'rab (kasus/modus).

Selanjutnya bagian ketiga, merupakan bagian terpenting dalam sintaksis Arab, yaitu pembentukan kalimat inti atau dikenal dengan istilah umdah al-kalam. Bagian ini bisa dikatakan sebagai pembuka dari tujuan utama dalam sintaksis, karena membicarakan tentag sesuatu yang lebih besar dari kata, atau dengan kata lain membicarakan bagaimana membentuk kalimat melalui kata-kata. ${ }^{15}$ Bagian ini terdiri dua bab, pembentukan kalimat nominal dan verbal disertai jenis-jenisnya. Kemudian bagian keempat memuat materi pelengkap kalimat aspek genitif, terdiri dari satu bab, yaitu tarkib idhafiy atau frasa nominal. Bagian kelima berisi pelengkap berupa tawabi', terdiri dari empat bab, yaitu tarkib na'tiy, badal (aposisi), taukid (penegas), dan athaf (konjungsi).

Kemudian bagian keenam membahas fungsi keterangan yang menjadi pelengkap dari aspek akusatif, terdiri dari satu bab tentang maf'ulat, meliputi 1 (2015): 35 .

${ }^{14}$ Fuad Munajat, "Pembelajaran Nahwu Dalam Prespektif Fungsional," Arabia 7, no.

${ }^{15}$ Chatim Shalih Dhamin, Ilmu al-Lughah (Universitas Baghdad, t.t.), 63. 
pembahasan tentang maf'ul mutlak, maf'ul li ajlih, maf'ul ma'ah, maf'ul fih, hal, tamyiz, dan istitsna'. Sedangkan bagian ketujuh merupakan bagian terakhir yang membahas pelengkap berupa amil nawasikh, yaitu masuknya kata pada kalimat nominal dan merubah struktur dan tatanan kalimat tersebut. Bagian ini terdiri dari tiga bab, yaitu kana wa akhawatuha, inna wa akhawatuba, dan dhanna waakhawatuba. Mulai dari bab keempat hingga terakhir disebut sebagai pelengkap, karena semua bab pada bagian tersebut merupakan fudhlah al-kalam atau pelengkap dari kalimat inti yang keberadaanya tidak bersifat wajib.

Pembahasan tiap bab pada masing-masing bagian disajikan dengan istilah-istilah yang telah dikontraskan antara nahwu dan linguistik umum, berikut dengan perbandingan antara konsep nahwu dan tata bahasa Indonesia. Analisis kontrastif memiliki peran yang paling penting dalam bahan ajar ini, karena menjadi penanda dan ciri khas, sekaligus sebagai pendekatan produk yang dikembangkan. Oleh sebab itu, penyusunan bahan ajar ini juga melibatkan dosen bahasa Indonesia, guna mendiskusikan tipologi sintaksis antara bahasa Arab dan bahasa Indonesia.

Beberapa penelitian tentang analysis kontrastif antara bahasa Arab dan bahasa Indonesia juga dijadikan sebagai referen. Seperti hasil penelitian yang dilakukan Badrudin tahun 2008 tentang penanda jumlah dalam bahasa Arab dan bahasa Indonesia, ${ }^{16}$ penelitian yang dilakukan oleh Alla tahun 2008 tentang klausa relative bahasa Indonesia dan bahasa Arab. ${ }^{17}$ Kemudian penelitian yang dilakukan Budiono tahun 2017 tentang verba resiprokal dalam bahasa Arab dan bahasa Indonesia. ${ }^{18}$ Penelitian-penelitian tersebut memberikan kontribusi besar dalam penyusunan bahan ajar yang dikembangkan, di samping beberapa tulisan lain yang juga menjadi referensi.

Pengkajian tipologi sintaksis antara bahasa Arab dan Indonesia tidak semudah membalikkan telapak tangan, karena keduanya memiliki tipe bahasa yang berbeda. Bahasa Arab bertipe fleksi, yaitu bahasa yang hubungan gramatikalnya tidak dinyatakan dengan urutan kata, tetapi dinyatakan dengan infleksi atau tasrif lmghawiy. Perubahan bentuk kata menjadi penanda bahasa infleksional dilalui dengan cara deklinasi dan konjugasi. Deklinasi adalah perubahan bentuk kata yang disebabkan oleh jenis, jumlah, dan kasus. ${ }^{19}$

${ }^{16}$ Ali Badrudin dan Prof Soepomo Poedjosoedarmo, "Penanda jumlah dalam bahasa Arab dan bahasa Indonesia: Studi gramatika kontrastif” (Universitas Gadjah Mada, 2008).

${ }^{17}$ Ahmed Saber Abd Alla dan Prof Dr Soepomo Poedjosoedarmo, "Klausa relatif bahasa Indonesia dan klausa relatif bahasa Arab :: Sebuah studi kontrastif” (Universitas Gadjah Mada, 2008).

${ }^{18}$ Taat Budiono dan S. U. Prof. Dr. I Dewa Putu Wijana, "Verba Resiprokal Dalam Bahasa Arab Dan Bahasa Indonesia (Sebuah Studi Kontrastif)" (Universitas Gadjah Mada, 2016).

${ }^{19}$ Harimurti Kridalaksana, Kamus Linguistik (Jakarta: Gramedia, 2009), 45. 
Sedangkan konjugasi adalah perubahan bentuk kata yang disebabkan oleh perubahan persona, jumlah, dan kala. ${ }^{20}$

Sementara bahasa Indonesia bertipe aglutinatif, yaitu tipe bahasa yang proses pembentukan kata dilakukan dengan afiksasi, komposisi atau pemajemukan, dan reduplikasi. ${ }^{21}$ Perbedaan tipe bahasa ini menjadikan ketidaksejajaran sintaksis bahasa Arab dan Indonesia. Bahkan, tidak sedikit konsep sintaksis dalam bahasa Arab tidak dimiliki bahasa Indonesia. Adapun hasil analisis kontrastif antara bahasa Arab dan Indonesia tercermin dalam beberapa istilah berikut.

\begin{tabular}{|c|c|c|}
\hline No. & Bahasa Arab & Bahasa Indonesia \\
\hline 1 & I'rab al-ism & Kasus \\
\hline 2 & Rafa' & Nominatif \\
\hline 3 & Nashab & Akusatif \\
\hline 4 & Jarr & Genitif \\
\hline 5 & I'rab al-fi'l & Modus \\
\hline 6 & Rafa' & Indikatif \\
\hline 7 & Nashab & Subjungtif \\
\hline 8 & Ja:m & Jusif \\
\hline 9 & Jumlab ismiyah & Kalimat nominal \\
\hline 10 & Jumlah fi'liyah & Kalimat verbal \\
\hline 11 & Idhafab & Frasa nominal non-adjektif \\
\hline 12 & Tarkib na'tiy & Frasa nominal adjektif \\
\hline 13 & Bada1 & Aposisi \\
\hline 14 & Taukid & Penegas \\
\hline 15 & Ataf & Konjungsi \\
\hline 16 & Ism nakirah & Nomina indefinite \\
\hline 17 & Ism ma'rifah & Nomina definit \\
\hline 18 & Fi'l muta'addiy & Verba transitif \\
\hline 19 & Fi'l lazim & Verba intransitif \\
\hline 20 & Fi'l majbul & Verba pasif \\
\hline
\end{tabular}

\section{Tabel 1. Beberapa istilah hasil analisis kontrastif}

Perbandingan istilah di atas secara visual terlihat sejajar. Akan tetapi secara konseptual, kedua istilah memiliki struktur dalam yang berbeda. Bahkan terdapat kaidah dalam bahasa Arab yang secara fungsi sintaksis tidak dimiliki oleh bahasa Indonesia, semisal al-maf'ul muthlaq, al-maf'ul li ajlibi, al-maf'ul fih (dharf), al-maf'ul ma'ah, chal, tamyiz, dan istitsna'. Semua istilah tersebut tidak dapat disejajarkan dalam bahasa Indonesia, kecuali hanya diekspresikan sebagai fungsi

${ }^{20}$ Harimurti Kridalaksana, 131.

${ }^{21}$ Isra Mirdayanti, Najmuddin Abd Safa, dan Kaharuddin Kaharuddin, "Analisis Kontrastif Verba Dalam Bahasa Arab dan Bahasa Indonesia Serta Implikasinya Dalam Pembelajaran Bahasa Arab," Jurnal Ilmu Budaya 6, no. 2 (13 Desember 2018): 265. 
keterangan tunggal. Hal lain yang juga tidak dimiliki dalam kaidah bahasa Indonesia adalah amil nawasikh, yang terdiri dari inna wa akbawatuha, kana wa akhawatuba, dan dhanna wa akbawatuba. Ketiganya merusak susunan kalimat nominal.

Konsep ini tidak dijumpai dalam bahasa Indonesia, karena tiap kata dalam kalimat tidak mempengaruhi kata yang lain. Perbedaan beberapa konsep karena ketidaksetaraan aspek sintaksis tersebut dikhawatirkan akan menyulitkan mahasiswa memahami nahwu. Oleh karena itu, untuk tujuan pedagogik beberapa konsep yang berbeda dijelaskan hanya pada taraf struktur luar, dengan asumsi bahwa tidak semua mahasiswa memahami tata bahasa Indonesia secara mendalam.

Pemanfaatan pendekatan kontrastif antara bahasa Indonesisa dan bahasa Arab diharapkan mampu untuk mengatasi masalah interferensi pada keterampilan berbahasa, khususnya keterampilan menulis dengan cara memberikan pola-pola pembentukan kalimat bahasa Arab yang sesuai kaidah nahwu. Atas dasar itu, bahan ajar yang dikembangkan dilengkap dengan penyajian rumus-rumus pembentukan frasa, klausa, dan kalimat berbahasa Arab sesuai dengan masing-masing tema. Fungsi rumus ini dimaksudkan untuk memudahkan mahasiswa memahami konsep sekaligus praktik.

\begin{tabular}{|c|c|}
\hline \multicolumn{2}{|c|}{ KAIDAH PENYUSUNAN KALIMAT VERBAL I } \\
\hline Verba (fi'i) & Subjek (fa'il) \\
\hline $\begin{array}{l}\text { 1. Verba menyesuaikan subjek dari aspek } \\
\text { kategori jender, artinya jika subjek } \\
\text { menunjukkan nomina untuk perempuan, } \\
\text { maka verba juga diberikan penanda } \\
\text { perempuan. }\end{array}$ & $\begin{array}{l}\text { 3. Subjek berupa nomina yang nominatif } \\
\text { (ism marfi'), dan terletak setelah verba. }\end{array}$ \\
\hline $\begin{array}{l}\text { 2. Verba tidak dikenai perubahan ketika } \\
\text { jumlah subjek menunjukkan makna } \\
\text { lebih dari satu, baik itu ganda ataupun } \\
\text { jamak. }\end{array}$ & $\begin{array}{l}\text { 4. Subjek bisa berupa isim dhahir, yaitu } \\
\text { nomina nampak yang menunjukkan } \\
\text { sesuatu yang dinamai, dan bisa juga } \\
\text { berupa isim dhamir, yaitu berupa kata } \\
\text { ganti atau pronomina. }\end{array}$ \\
\hline \multicolumn{2}{|c|}{$\begin{array}{c}\text { Rumus kalimat verbal 1: } \\
\text { Predikat (f'il) + Subjek (fa'il) }\end{array}$} \\
\hline & $+\mathrm{S}$ \\
\hline
\end{tabular}

Gambar 1. Contoh kaidah dan rumus pembentukan kalimat verbal dalam bahan ajar 


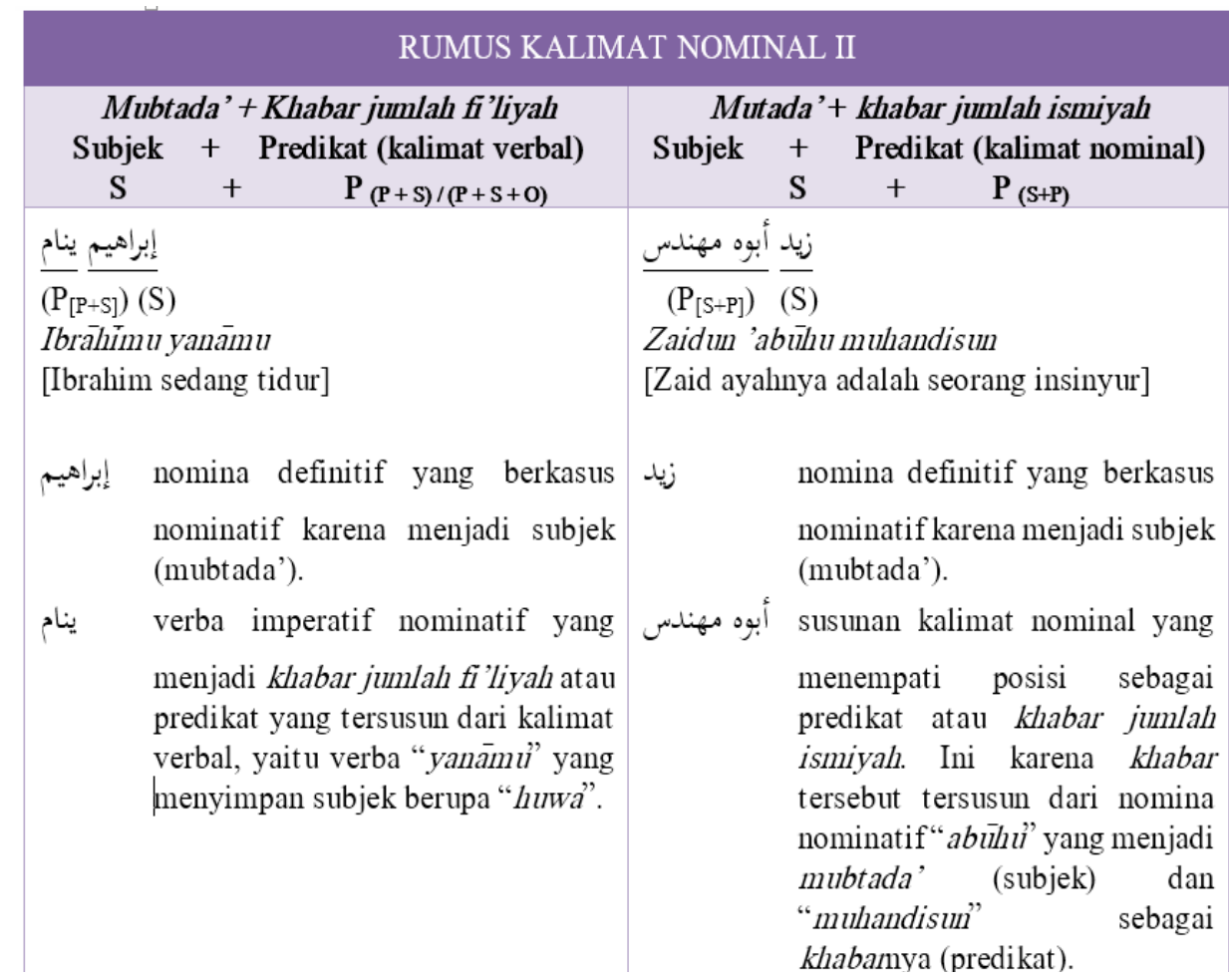

\section{Gambar 2. Contoh kaidah dan rumus pembentukan kalimat nominal dalam bahan ajar}

Selain rumus, bahan ajar ini juga dilengkapi contoh-contoh sederhana beserta analisis kata perkata tiap contoh. Ini dilakukan agar para mahasiswa lebih mengetahui jabatan kata dalam kalimat secara spesifik. Contoh-contoh yang digunakan terbilang sederhana, dengan menggunakan kosakata yang biasa dipakai sehari-hari dalam berkomunikasi. Contoh-contoh kalimat juga disertai dengan trasliterasi dan artinya, dengan tujuan agar mahasiswa yang baru pertama kali mempelajarinya merasa dimudahkan.

Kemudian sebagai bentuk evaluasi, bahan ajar ini memuat latihan-latihan soal yang disajikan secara praktis, bukan soal-soal yang sifatnya definitif, karena pada dasarnya pembelajaran nahwu memadukan secara bersama-sama antara pemahaman konsep dan praktik. Selain itu, soal-soal evaluasi yang disajikan juga berada pada level create, seperti perintah membuat kalmiat yang sesuai dengan tema, sehingga hal tersebut mengajak mahasiswa untuk berpikir kritis. 
E. Latihan

1. Identifikasi kalimat nominal dalam paragraf di bawah ini !

$$
\begin{aligned}
& \text { خلا طلب وكنلك صنيقه حازّ، ها ينزُسان فى جامعة واحدة، واختلف خالد عن حلزم، خلالد سمين جذا، وحلزم }
\end{aligned}
$$

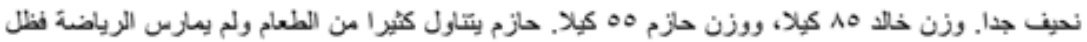

$$
\begin{aligned}
& \text { نحيفا. وأها خالد بمارس الزرياضة كل بوم ولكنه ظل عمبينا لأنه بأكل كثير ا. }
\end{aligned}
$$

2. Tentukan dua unsur kalimat nominal dalam tabel berikut !

\begin{tabular}{|c|c|c|c|}
\hline No. & Kalimat & Subjek & Predikat \\
\hline 1 & كيف حلث? & & \\
\hline 2 & الكهب العلعيةً في المكتبة & & \\
\hline 3 & في المبذان مبازة كرة التقم & & \\
\hline 4 & العذو أمامئا & & \\
\hline 5 & محف طلب الجامعنة & & \\
\hline 6 & الحنرِقة وراه النبت & & \\
\hline 7 & الموظف يرتب الكثب & & \\
\hline 8 & التهبوة طعهبا مر & & \\
\hline
\end{tabular}

3. Tentukan jenis predikat (khabar) dari kalimat berikut !

\begin{tabular}{|c|c|c|}
\hline No. & Kalimat & Jenis Predikat \\
\hline 1 & أنا طالب جذيد & \\
\hline 2 & خالّ بئب إلىى الجامعةً & \\
\hline 3 & الأسئادّ في كاعة المحاضرة & \\
\hline 4 & محمد يبئه جميل & \\
\hline 5 & أبي مذرس المدزسة & \\
\hline 6 & القهوة خير صنيث & \\
\hline 7 & هذا الكُّاب موضعه طريف & \\
\hline 8 & فيصل عامل نشيط & \\
\hline
\end{tabular}

4. Tulislah kalimat nominal yang terdiri dari

a. Subjek dan predikat yang berupa kata

b. Subjek dan predikat yang berupa kalimat verbal

c. Subjek dan predikat yang berupa kalimat nominal

d. Subjek dan predikat yang berupa frasa preposisional

e. Subje dan predikat yang berupa frasa adverbial

\section{Gambar 3. Contoh latihan soal dalam bahan ajar}

\section{Validitas Bahan Ajar}

Proses validasi melibatkan dua pakar linguistik Arab dan umum, terdiri dari satu pakar linguistik Arab dari Universitas KH. A. Wahab hasbullah, dan pakar linguistik umum dari Universitas Brawijaya Malang. Dalam instrument validasi bahan ajar, terdapat 15 butir penilaian yang digunakan untuk mengukur kelayakan buku dari aspek materi, meliputi kelengkapan materi, keluasannya, ketepatan konseptual, keakuratan tipologi pengontrasan antara kaidah bahasa Arab dan bahasa Indonesia, serta hal-hal yang berkaitan dengan kelengkapan struktur buku ajar. Masing-masing butir memuat minimal skor 1 dan maksimal 4. 


\begin{tabular}{|c|c|c|c|}
\hline Validator & Skor maksimal & Hasil penilaian & Persentase \\
\hline 1 & 64 & 58 & 90,62 \\
\hline 2 & 64 & 56 & 87,5 \\
\hline Jumlah & 128 & 114 & 89,1 \\
\hline
\end{tabular}

Tabel 2. Hasil validasi

Hasil validasi menyatakan bahwa bahan ajar yang dikembangkan mencapai kriteria sangat valid dengan perolehan persentase 89,1\%. Angka tersebut menunjukkan bahwa bahan ajar nahwu berbasis kontrastif memiliki kualifikasi sangat layak. Meski demikian, ada beberapa catatan dan masukan sebagai bentuk perbaikan bahan ajar agar mencapai taraf kesempurnaan yang diharapkan. Di antara catatan dan masukan tersebut adalah terdapat beberapa kaidah dalam bahasa Arab yang tidak dapat disejajarkan langsung dengan tata bahasa Indonesia, sehingga perlu dijelaskan terlebih dahulu. Selain itu, bahan ajar juga perlu ditambahkan contoh-contoh dalam tabel sebagai perbandingan hasil pengontrasan antara bahasa Arab dan bahasa Indonesia.

\section{Uji Coba Lapangan}

Setelah melalui tahap validasi dan revisi, peneliti melakukan uji coba yang dimulai dari pemberian pretes, penerapan bahan ajar, dan diakhiri postes. Pretes ini dimaksudkan untuk mengetahui kemampuan awal para mahasiswa dalam pembelajaran nahwu. Meskipun pada dasarnya dosen telah mengetahui kemampuan rata-rata mahasiswa melalui refleksi perkuliahan di kelas bahwa tidak sedikit mahasiswa yang belum memahami nahwu. Hasil refleksi tersebut dibuktikan melalui nilai pretes mahasiswa yang rata-ratanya hanya mencapai $66.08 \%$.

Uji coba terbatas ini dilakukan dengan pemberian perlakuan berupa penerapan bahan ajar nahwu berbasis kontrastif. Dikatakan uji coba terbatas karena hanya 8 kali tatap muka dengan materi ajar yang terbatas, yaitu; materi i'rab al-ism atau kasus yang meliputi nominatif (rafa), akusatif (nashab), genitif (jarr), dan i'rab al-fi'l atau modus yang meliputi indikatif (rafa), subjungtif (nashab), dan jusif (ja:m); serta materi pembentukan kalimat (tarkib al-jumal) yang meliputi kalimat verba (jumlah fi'liyah) dan kalimat nominal (jumlah ismiyah).

Dipilihnya materi i'rab dan pembentukan kalimat didasarkan asumsi bahwa i'rab merupakan penentu jabatan tiap kata yang terdeteksi melalui perubahan akhir kata, sehingga ia menempati posisi terpenting dalam nahwu. Sedangkan pembentukan kalimat merupakan tujuan inti dari nahwu. Di sisi lain, nahwu memiliki ruang lingkup yang luas, sehingga tidak mungkin semua materi diajarkan pada tahap uji coba bahan ajar. 


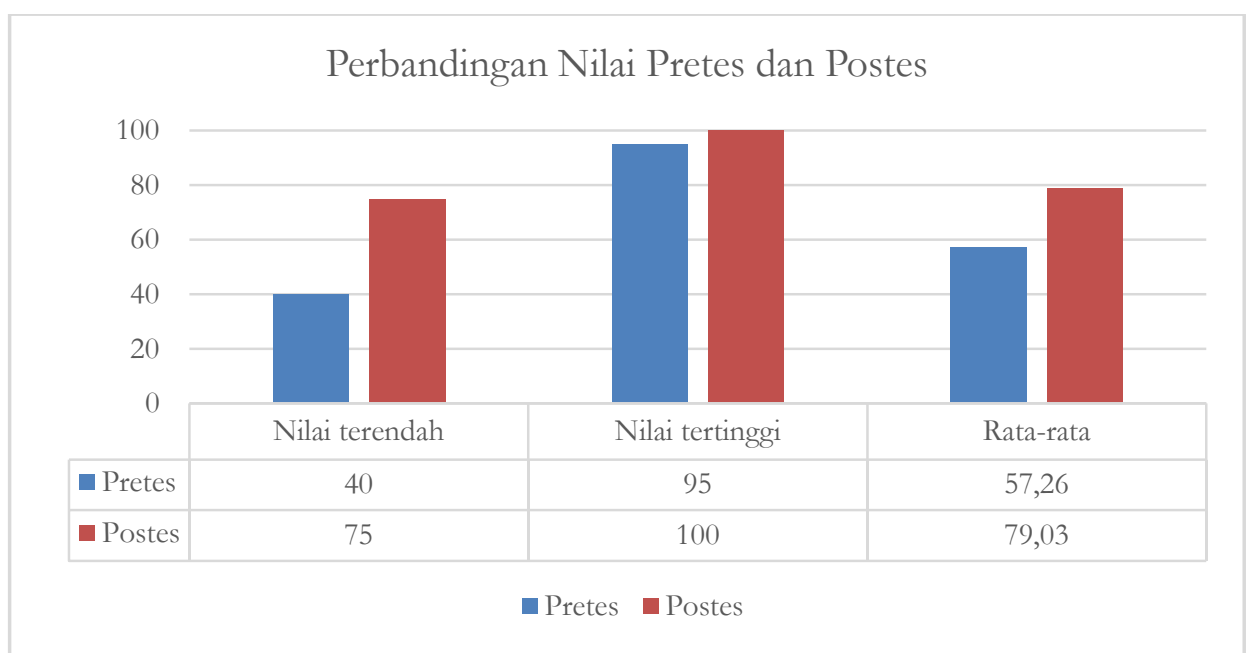

\section{Gambar 1. Grafik perbandingan nilai pretes dan postes}

Data pada gambar 1 di atas menunjukkan bahwa hasil belajar para mahasiswa pada matakuliah nahwu mengalami peningkatan yang cukup signifikan, dibuktikkan dengan perbandingan nilai terendah dan tertinggi pada nilai pretes dan postes. Sebelum diberikan perlakuan berupa penerapan bahan ajar, hasil pretes hanya mencapai rata-rata $57,26 \%$. Akan tetapi setelah diberikan perlakuan, rata-rata nilai postes sebesar $79,03 \%$. Dengan demikian terdapat peningkatan sebesar $21,77 \%$ antara pretes dan postes.Hal ini dapat diartikan bahwa bahan ajar nahwu berbasis pendekatan kontrastif dapat meningkatkan hasil belajar siswa yang juga berjalan beriringan dengan meningkatnya pemahaman yang cukup signifikan terhadap materi nahwu.

\section{Hasil Kuesioner}

Instrumen kuesioner digunakan untuk mengetahui respon mahasiswa terhadap bahan ajar yang telah diterapkan. Kuesioner ini diberikan kepada siswa pada pertemuan terakhir setelah uji coba lapangan. Terdapat 5 komponen yang dijadikan sebagai penilaian, yaitu aspek kemudahan memahami konsep, kemudahan dalam praktik penerapan konsep, kemudahan penggunaan bahan ajar, glosarium yang dapat membantu memahami konsep, dan terakhir yaitu perasaan senang dalam belajar nahwu.

\begin{tabular}{|c|c|c|c|}
\hline Hasil Angket & Skor Maksimal & Hasil Penilaian & Persentase \\
\hline Jumlah & 260 & 241 & $93 \%$ \\
\hline
\end{tabular}

Tabel 3. Hasil persentase kuesioner 


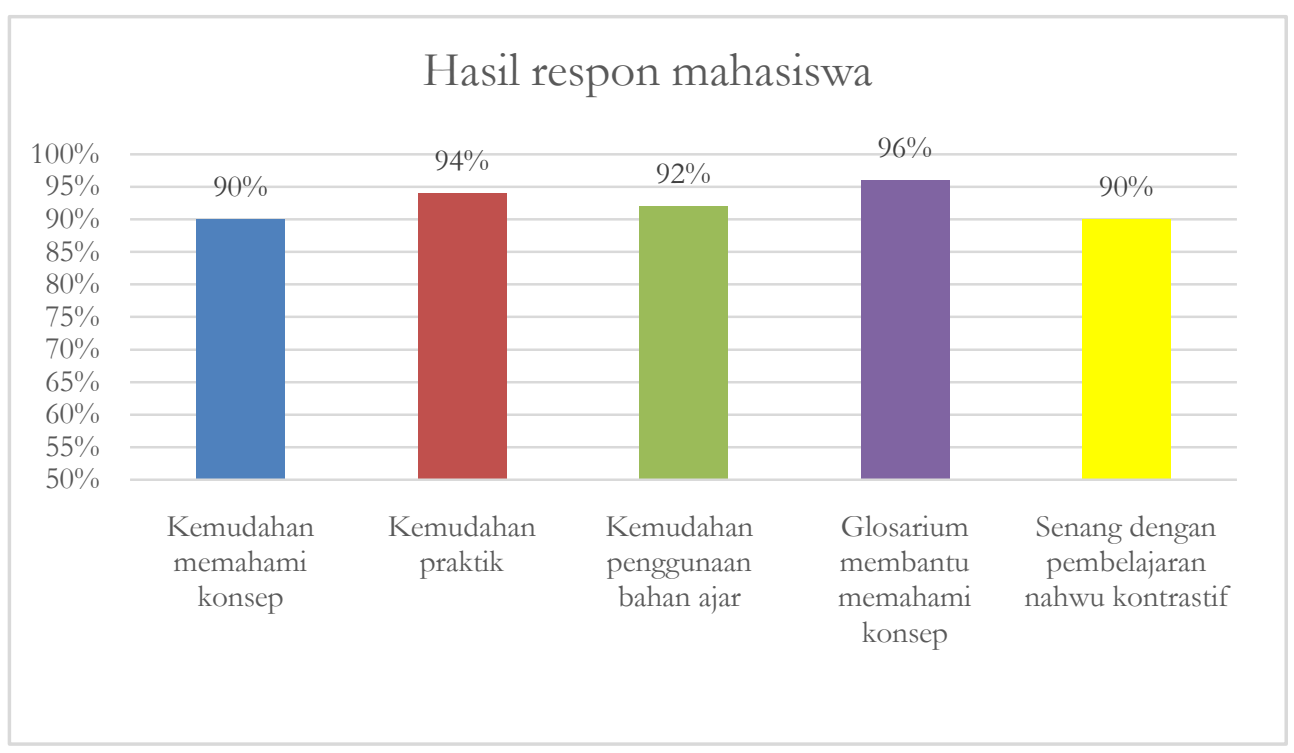

\section{Gambar 2. Persentase hasil kuesioner respon mahasiswa}

Visualisasi hasil kuesioner di atas dapat diartikan bahwa bahan ajar yang dikembangkan mendapat respon yang baik dari para mahasiswa. Hal tersebut ditengarai melalui hasil kuesioner secara umum yang mencapai 93\% dengan kualifikasi sangat valid. Adapun penilaian detail tercermin dalam gambar 2 yang menunjukkan bahwa pada komponen kemudahan mahasiswa memahami konsep mencapai $90 \%$, kemudahan praktik penerapan konsep mencapai 94\%, dan kemudahan penggunaan bahan ajar memperoleh rata-rata sebesar 92\%. Kemudian glosarium yang tersaji di bagian akhir bahan ajar juga turut membantu mahasiswa dalam memamahi konsep, oleh karenanya aspek ini mencapai rata-rata sebesar $96 \%$.

Hasil kuesioner pada aspek terakhir yang memperoleh rata-rata sebesar 90\%dapat diartikan bahwa sebagian besar mahasiswa merasa lebih senang memahami nahwu melalui pendekatan kontrastif.Selain itu, meningkatnya hasil belajar sebagaimana disampaikan di atas, juga menandai bahwa mereka semakin termotivasi untuk mempelajari nahwu. Para mahasiswa merasa lebih bersemangat mempelajari nahwu dengan kemudahan konsep yang ditawarkan melalui pendekatan kontrastif. Meningkatnya motivasi dan hasil belajar ini menjadi tanda bahwa bahan ajar yang dikembangkan efektif, efisien, dan dapat dijadikan buku pegangan bagi mahasiswa.

Contoh pola-pola kalimat bahasa Arab yang dibentuk oleh rumus-rumus suatu konsep sintaksis tertentu menjadikan para mahasiswa tidak hanya memahami kaidah-kaidah saja, melainkan juga praktik penerapan kaidah secara verbal. Hal ini merujuk pada fungsi utama sintaksis yang pada hakikatnya adalah ilmu terapan sebagai kontrol sistem komunikasi. Dalam hal ini, respon mahasiswa terhadap latihan-latihan praktis yang menjadi tolak ukur kompetensi 
dirasa mampu menjembatani antara kaidah dan praktik, karena latihan-latihan yang disajikan di tiap akhir bab semuanya berisi latihan yang sifatnya praktis, bukan definitif.

\section{Upaya Mengatasi Interferensi Bahasa Indonesia Dalam Bahasa Arab}

Sebagaimana disebutkan di atas bahwa dikembangkannya bahan ajar ini bermula dari adanya interferensi bahasa Indonesia dalam tulisan berbahasa Arab para mahasiswa yang disebabkan oleh lemahnya tingkat pemahaman terhadap nahwu. Maka dari itu, dalam penelitian ini terdapat dua variable berbeda yang saling berkaitan, yaitu lemahnya pemahaman nahwu dan terjadinya interferensi dalam kemahiran menulis mahasiswa. Keduanya merujuk pada kata kunci nahwu dan kemahiran menulis yang pembelajarannya seringkali terpisah. Di dalam nahwu dipelajari bagaimana cara berbahasa Arab yang baik dan benar, sedangkan dalam kemahiran menulis dipelajari bagaimana menghasilkan tulisan berbahasa Arab yang baik dan benar sesuai nahwu. Sudah barang tentu keduanya menjadi matakuliah yang berdiri sendiri.

Kaitannya dengan penelitian ini, bahan ajar yang dikembangkan diperuntukkan bagi matakuliah nahwu, dan hasilnya difungsikan untuk mengatasi permasalahan dalam matakuliah kitabah yang disebabkan oleh lemahnya pemahaman nahwu. Maka, guna mengetahui kelayakan dan efektifitas bahan ajar ini sebagai solusi untuk mengatasi unsur interferensi bahasa Indonesia dalam bahasa Arab, diperlukan analisis terhadap hasil validasi serta melalui pengukuran hasil tulisan mahasiswa (product measures).

Berbicara kelayakan, bahan ajar yang dikembangkan memiliki kualifikasi sangat layak dengan memperoleh rata-rata sebesar $89,1 \%$ dari dua validator sebagaimana yang telah disajikan dalam tabel 2. Adapun rinciannya, dari validator pertama diperoleh rerata mencapai $90,62 \%$, sehingga dinyatakan dengan kualifikasi sangat layak. Sedangkan hasil penilaian dari validator kedua yang notabene pakar linguistik umum diperoleh rerata sebesar 87,5\% dengan kualifikasi layak. Hasilpenilaian tersebut menunjukkan bahwa bahan ajar nahwu melalui pendekatan kontrastif dapat dijadikan sebagai rujukan bagi mahasiswa.

Selanjutnya, untuk mengetahui besar kecilnya tingkat interferensi bahasa Indonesia dalam tulisan mahasiswa Pendidikan Bahasa Arab, peneliti melakukan pembandingan sebagaimana terdapat pada gambar1 antara hasil pretes dan postes yang terpaut 21,7\%. Hasil tersebut menunjukkan bahwa pemahaman mahasiswa terhadap nahwu meningkat secara signifikan. Hasil ini semakin menegaskan bahwa bahan ajar nahwu berbasis pendekatan kontrastif layak dan efektif untuk meningkatkan minat dan motivasi belajar mahasiswa yang ditunjukkan melalui meningkatnya pemahaman nahwu.

Guna mengetahui aspek interferensi, peneliti melakukan analisis lanjutan terhadap butir soal uji kompetensi kognitif. Hasil analisis menyatakan bahwa 
tingkat pemahaman nahwu memberikan pengaruh besar sebagai bentuk solusi untuk meminimalkan unsur-unsur interferensi sintaksis bahasa Indonesia terhadap bahasa Arab. Hal ini dibuktikan dengan berkurangnya kesalahankesalahan kaidah nabwiyah dalam hasil postes. Adapun kesalahan yang banyak terjadi dalam hasil pretes terletak pada aspek konkordansi atau persesuaian (dalam istilah Arab disebut muthabaqah) yang meliputi persesuaian antara subjek dan predikat dari segi jenis (mudzakkar-muannats) dan jumlah (mufrad, tatsniyah, jama) baik dalam kalimat nominal ataupun verbal.

Ryding dalam magnum ospusnya mengemukakan bahwa konkordansi merupakan salah satu dari tiga prinsip fundamental dalam pembentukan kalimat berbahasa Arab. ${ }^{22}$ Sementara dua lainnya berupa government atau amildan urutan kata. Dua dari tiga prinsip tersebut tidak dijumpai dalam gramatika bahasa Indonesia, yaitu konkordansi dan amil. Sedangkan urutan kata menjadi unsur prinsipiil yang menjadi penanda fungsi oleh kedua bahasa. Maka dari itu, tidak mengherankan jika perbedaan sistem ini menghadirnya interferensi bahasa Indonesia terhadap bahasa Arab yang berimbas pada munculnya kesalahankesalahan nabwiyah.

Konkordansi menjadi hal yang paling banyak melahirkan kesalahan, karena dalam bahasa Indonesia tidak mengenal adanya kesesuaian antara subjek dan predikat dari aspek jenis dan jumlah. Seperti kalimat "kita pergi ke sekolah". Kata "pergi" tidak mengalami perubahan meskipun subjek berupa nomina tunggal ataupun jamak. Sedangkan dalam bahasa Arab, verba selalu dipengaruhi oleh subjek. Perbedaan tersebut dikarenakan perbedaan tipe bahasa Indonesia yang berupa aglutinasi, dan bahasa Arab yang beripe fleksi.

Unsur interferensi yang juga kentara adalah pola kalimat pasif. Dalam bahasa Arab, kalimat pasif terdiri dari subjek dan verba. Namun perlu diketahui bahwa subjek yang diistilahkan "naib al-fa'il" awalnya adalah objek, dan pelaku dalam makna sebenarnya dihilangkan. Sedangkan dalam bahasa Indonesia diperbolehkan mengikutsertakan pelaku. Dominasi pola kalimat pasif dalam bahasa Indonesia ini cukup kuat, sehingga tidak sedikit mahasiswa yang salah dalam membuat kalimat pasif. Di antara contoh kesalahannya, ditemukan kalimat "الحبز أُكِلَ فرمان" / al-bubæu ukila firman/.

Permasalahan interferensi tersebut mulai terkikis seiring meningkatnya pemahaman para mahasiswa terhadap materi nahwu setelah dilakukan implementasi bahan ajar yang telah dikembangkan. Peningkatan ini Oleh karena itu, bahan ajar ini dianggap mampu mengatasi problem interferensi bahasa Indonesia dalam bahasa Arab. Meskipun tingkat keabsahan hasil analisis pretes dan postes sebagai instrument untuk mengetahui tingkat interferensi dapat

${ }^{22}$ Karin C. Ryding, A Reference Grammar of Standard Arabic (Cambridge: Cambridge University Press, 2005), 57. 
dibilang masih kecil, namun hasil penelitian ini setidaknya dapat dijadikan informasi awal bahwa bahan ajar ini mampu meningkatkan pemahaman nahwu yang juga berkontribusi dalam mengatasi masalah interferensi.

\section{Penutup}

Bahan ajar nahwu atau sintaksis berbasis pendekatan kontrastif dinilai sangat layak untuk diterapkan dalam pembelajaran nahwu. Hal itu karena hasil validasi menyatakan bahwa bahan ajar ini dinilai sangat layak dengan rerata persentase sebesar $89,1 \%$. Di samping itu, hasil uji coba juga menunjukkan adanya peningkatan hasil belajar para mahasiswa dalam materi nahwu sebesar $21,77 \%$. Peningkatan hasil belajar tersebut juga diartikan sebagai peningkatan pemahaman mahasiswa, di mana ia memberikan kontribusi yang besar terhadap berkurangnya kesalahan-kesalahan berbahasa Arab karena adanya dominasi bahasa Indonesia.

Berkurangnya tingkat interferensi ditunjukkan melalui hasil analisis terhadap hasil pretes dan postes yang menyatakan bahwa sebagian besar tulisan mahasiswa telah mengikuti struktur sesuai kaidah nahwu. Bahkan unsur-unsur interferensi bahasa Indonesia berangsur hilang seiring dengan meningkatnya pemahaman para mahasiswa dalam kaidah-kaidah sintaksis. Ini menunjukkan bahwa bahan ajar yang dikembangkan efektif untuk mengatasi masalah interferensi. Meski demikian, perlu dilakukan penelitian lanjutan dengan menggunakan rancangan eksperimen guna melihat tingkat validitas yang tinggi mengenai seberapa besar efektifitas bahan ajar yang dikembangkan dalam mengatasi interferensi. 


\section{Bibliografi}

Al-Khuli, Muhammad Ali. “Ta'tsiru al-Tadakhkhul al-Lughawiy fiy Ta'allumi alLughah al-Tsaniyah wa Ta'limuha." Majallah Jami'ah Malik Saud 1, no. 2 (1989): 109-28.

Alla, Ahmed Saber Abd, dan Prof Dr Soepomo Poedjosoedarmo. "Klausa relatif bahasa Indonesia dan klausa relatif bahasa Arab :: Sebuah studi kontrastif." Universitas Gadjah Mada, 2008.

Badrudin, Ali, dan Prof Soepomo Poedjosoedarmo. "Penanda jumlah dalam bahasa Arab dan bahasa Indonesia:: Studi gramatika kontrastif." Universitas Gadjah Mada, 2008.

Budiono, Taat, dan S. U. Prof. Dr. I Dewa Putu Wijana. "Verba Resiprokal Dalam Bahasa Arab Dan Bahasa Indonesia (Sebuah Studi Kontrastif).” Universitas Gadjah Mada, 2016.

Chaer, Abdul, dan Leoni Agustina. Sosiolinguistik: Perkenalan Awal. Jakarta: Rineka Cipta, 2010.

Dhamin, Chatim Shalih. Ilmu al-Lughah. Universitas Baghdad, t.t.

Harimurti Kridalaksana. Kamus Linguistik. Jakarta: Gramedia, 2009.

Hijriyah, Umi. Analisis Kontrastif Pembelajaran Bahasa Arab dan Bahasa Indonesia. Lampung: Fakta Press, 2014.

Mirdayanti, Isra, Najmuddin Abd Safa, dan Kaharuddin Kaharuddin. "Analisis Kontrastif Verba Dalam Bahasa Arab dan Bahasa Indonesia Serta Implikasinya Dalam Pembelajaran Bahasa Arab." Jurnal Ilmu Budaya 6, no. 2 (13 Desember 2018): 258-67.

Munajat, Fuad. "Pembelajaran Nahwu Dalam Prespektif Fungsional." Arabia 7, no. 1 (2015).

Nashoih, Afif Kholisun. "Pola Interferensi Sintaksis Bahasa Indonesia Dalam Bahasa Arab Pada Insya' Mahasiswa Pendidikan Bahasa Arab.” Prosiding Konfererensi Nasional Bahasa Arab 5, no. 5 (2019): 648-61.

-. "Revolusi Ilmiah Thomas Kuhn dan Relevansinya Terhadap Pengembangan dan Pengembangan Ilmu Nahw." JURNAL PUSAKA 6, no. 2 (27 Juni 2019): 1-16.

Nur, Tajudin. "Analisis Kontrastif Dalam Studi Bahasa." Arabi: Journal of Arabic Studies 1, no. 2 (31 Desember 2016): 64-74.

Nurbayan, Yayan. "Pengembangan Materi Ajar Balaghah Berbasis Pendekatan Kontrastif'. Jurnal Bahasa Dan Seni.” Bahasa Dan Seni: Jurnal Bahasa, Sastra, Seni, Dan Pengajarannya 38, no. 1 (2010). 
354 | Arabiyatuna : Jurnal Bahasa Arab, Vol. 3, No. 2, 2019

Raswan, Raswan. "Tadris Al-Nahwi al-Tsani'Ala Asasi al-Taqabuliy." Prosiding Pertemuan Ilmiah Internasional Babasa Arab, 13 Juli 2018.

Ryding, Karin C. A Reference Grammar of Standard Arabic. Cambridge: Cambridge University Press, 2005.

Seff, Faisal Mubarak, dan Muhammad Mukhtar. "Al-Muhadatsah al-Yaumiyyah Wa Tadakhkhul Lughah al-Umm Fiha." Prosiding Pertemuan Ilmiah Internasional Bahasa Arab XI, 13 Juli 2018.

Sugiyono. Metode Penelitian Pendidikan: Pendekatan Kuantitatif, Kualitatif dan R\&D. Bandung: CV. Alfabeta, 2015.

Wahab, Laode Abdul. "Pengembangan Bahan Ajar Qawaid Bahasa Arab Berbasis Mind Map untuk STAIN Kendari." Al-Iqzab: Jurnal Hasil-Hasil Penelitian 9, no. 2 (1 November 2014): 65-90.

Zagood, Mohammed Juma M. "A Contrastif Studi of Relativization in English and Arabic with Reference to Translation Pedagogy." Duham University, 2012. 